\title{
Angiogenesis gene expression in murine endothelial cells during post-pneumonectomy lung growth
}

\author{
Miao Lin ${ }^{1}$, Kenji Chamoto', Barry C Gibney', Grace S Lee, Dinee Collings-Simpson', Jan Houdek², \\ Moritz A Konerding ${ }^{2}$, Akira Tsuda ${ }^{3}$ and Steven J Mentzer ${ }^{1 *}$
}

\begin{abstract}
Although blood vessel growth occurs readily in the systemic bronchial circulation, angiogenesis in the pulmonary circulation is rare. Compensatory lung growth after pneumonectomy is an experimental model with presumed alveolar capillary angiogenesis. To investigate the genes participating in murine neoalveolarization, we studied the expression of angiogenesis genes in lung endothelial cells. After left pneumonectomy, the remaining right lung was examined on days 3, 6, 14 and 21 days after surgery and compared to both no surgery and sham thoracotomy controls. The lungs were enzymatically digested and $\mathrm{CD}_{3} 1^{+}$endothelial cells were isolated using flow cytometry cell sorting. The transcriptional profile of the $\mathrm{CD}_{3} 1^{+}$endothelial cells was assessed using quantitative real-time polymerase chain reaction (PCR) arrays. Focusing on 84 angiogenesis-associated genes, we identified 22 genes with greater than 4-fold regulation and significantly enhanced transcription $(p<.05)$ within 21 days of pneumonectomy. Cluster analysis of the 22 genes indicated that changes in gene expression did not occur in a single phase, but in at least four waves of gene expression: a wave demonstrating decreased gene expression more than 3 days after pneumonectomy and 3 sequential waves of increased expression on days 6, 14, and 21 after pneumonectomy. These findings indicate that a network of gene interactions contributes to angiogenesis during compensatory lung growth.
\end{abstract}

\section{Introduction}

In most circumstances, angiogenesis does not occur in the adult pulmonary circulation $[1,2]$. Although structural adaptations are well-documented in the bronchial circulation $[3,4]$, the evidence for angiogenesis in the pulmonary circulation is sparse [5]. Pulmonary angiogenesis has been demonstrated in a few animal models including biliary cirrhosis [6], chronic Pseudomonas infections [7], metastatic disease [8], and post-pneumonectomy lung growth [9]. The finding that experimental (monocrotaline) pulmonary hypertension induces angiogenesis in the pleura and bronchovascular bundle, but not in the alveolar capillaries [3], underscores the distinctive biology of pulmonary angiogenesis.

\footnotetext{
* Correspondence: smentzer@partners.org

'Laboratory of Adaptive and Regenerative Biology, Brigham \& Women's

Hospital, Harvard, Medical School, Boston MA, USA

Full list of author information is available at the end of the article
}

Post-pneumonectomy compensatory lung growth is a particularly intriguing example of pulmonary angiogenesis. Within weeks of pneumonectomy, compensatory lung growth has been documented in many mammalian species including rats [10], mice [11] and dogs [12]. Recent evidence indicates that lung growth does not reflect alveolar distension, but an increase in the number of alveoli [13]. Working in the dog model, Hsia and colleagues estimated that the remaining lung after right pneumonectomy increases its capillary blood volume $43 \%$ and the capillary surface area 34\% [9]. Using a design-based estimate of capillary length [14] and allometric scaling, a comparable increase in mouse lung blood volume implies sufficient angiogenesis for more than $3 \mathrm{~km}$ of new pulmonary vessels. The mechanism of this dramatic pulmonary vascular growth remains unclear.

Previous work in murine post-pneumonectomy compensatory lung growth has implicated a diverse set of

\section{Biomed Central}

(c) 2011 Lin et al; licensee BioMed Central Ltd. This is an Open Access article distributed under the terms of the Creative Commons Attribution License (http://creativecommons.org/licenses/by/2.0), which permits unrestricted use, distribution, and reproduction in any medium, provided the original work is properly cited. 
angiogenic and growth-related genes including epidermal growth factor (Egr1) [15], keratinocyte growth factor (Fgf7) [16], hepatocyte growth factor (Hgf )[17], hypoxiainducible factor-1 $\alpha$ (Hifla) [18], endothelial nitric oxide synthase (Nos3) [19], platelet-derived growth factor $\beta$ (Pdgfb [20], and vascular endothelial growth factor (Vegfa) [21]. Attempts to define transcriptional regulation using microarrays and bulk RNA, however, have identified few genes clearly associated with capillary angiogenesis [22,23].

The complex morphogenetic changes in the growing lung include epithelial and stromal growth as well as pulmonary vascular angiogenesis. This dynamic process of tissue morphogenesis suggests a coordinated process involving complex network interactions and intercellular signaling. In this report, we study a transcriptional signaling of a central component pulmonary angiogenesis; namely, the pulmonary endothelium.

\section{Methods}

Mice

Male C57/B6 mice (Jackson Laboratory, Bar Harbor, Maine), 25 to $33 \mathrm{gm}$, were used in all experiments. The care of the animals was consistent with guidelines of the American Association for Accreditation of Laboratory Animal Care (Bethesda, MD); all animal protocols were reviewed and approved by the Institutional Care and Use Committee.

\section{Gene expression study design}

The age-matched mice received identical care prior to selection for one of three experimental groups: 1) no surgery control, 2) sham thoracotomy control, and 3) left pneumonectomy. Experimental time points were at Day 0, 3, 6, 14 and 21 days. Day 0 studied gene expression in the right lung without any prior surgery (sham thoracotomy or left pneumonectomy) $(\mathrm{N}=15$ mice). Days 3, 6, 14 and 21 compared the right lung after left pneumonectomy with no surgery controls ( $\mathrm{N}$ $\geq 9$ mice each time point). Day 14, the day reflecting expression of the peak number of statistically significant genes, compared all three experimental groups (left pneumonectomy, sham thoracotomy and no surgery controls)( $\mathrm{N}=9$ mice per condition). In each experimental group, enzymatic digestion of the right lung was followed by isolation of the CD $31^{+} \mathrm{CD} 11 \mathrm{~b}^{-}$ "endothelial cells" by flow cytometry cell sorting. In some experiments, three parameter $\left(\mathrm{CD} 31^{+} \mathrm{CD} 11 \mathrm{~b}\right.$ $\mathrm{CD}^{-} 5^{-}$) cell sorting was used. For the endothelial analysis presented, no significant difference between 2 and 3 parameter sorting was identified. RNA was isolated from the endothelial cells and used for characterizing angiogenesis-related gene expression.

\section{Pneumonectomy}

After anesthesia and intubation, the animal was ventilated on a Flexivent (SciReq, Montreal, QC Canada) at ventilator settings of $200 / \mathrm{min}, 10 \mathrm{ml} / \mathrm{kg}$, and PEEP of 2 $\mathrm{cmH}_{2} \mathrm{O}$ with a pressure limited constant flow profile [24]. A thoracotomy was created in the left fifth intercostal space. The hilum was ligated with a 5-0 surgical silk tie (Ethicon, Somerville, NJ) and the lung sharply excised. A recruitment maneuver involving a $3 \mathrm{sec}$ ramp to $30 \mathrm{cmH}_{2} \mathrm{O}$ and a $3 \mathrm{sec}$ plateau was performed while closing the thoracotomy with a 3-0 silk stitch (Ethicon). At the completion of the procedure, the animal was removed from the ventilator, maintained on a warming blanket and observed for spontaneous ventilation. The FlexiVent (SCIREQ) system was used to determine lung volumes at a $30 \mathrm{cmH}_{2} \mathrm{O}$ inflation pressure [24].

\section{Immunohistochemical staining}

Cryostat sections were obtained from lung specimens perfused with O.C.T. compound and snap frozen. The slides were serum blocked and treated with anti-Ki-67 (Clone TEC-3, Dako, Hamburg, Germany) monoclonal antibodies $(\mathrm{mAb})$ at $10-20 \mathrm{ug} / \mathrm{m}$ for one hour. After rinsing, the anti-Ki-67 binding was detected with an avidin-biotin-peroxidase complex (Vectastatin ABC-Kit, Vector Laboratories) or with the Envision ${ }^{\circledR}$ kit (Dako) and counter-stained with hematoxylin.

\section{Lung digestion}

The lung was processed in a modification of a procedure previously described [25]. Briefly, the lung was harvested at the airway to minimize extra pulmonary airway. The lung parenchyma was minced into $1 \mathrm{~mm}^{3}$ pieces and processed by enzymatic digestion: $1 \mathrm{mg} / \mathrm{ml}$ collagenase (Sigma, St. Louis, MO) and $2.5 \mathrm{U} / \mathrm{ml}$ dispase solution (Collaborative Biomedical Products, Bedford MA). The suspension was incubated at $37^{\circ} \mathrm{C}$ on a rotary shaker for $40 \mathrm{~min}$. The lung was triturated using an 18 g needle and filtered through a 70 um nylon mesh screen (BD Falcon, Bedford, MA) prior washing in serum containing RPMI-1640 medium (Thermo scientific, Pittsburgh, PA). Cells were treated with red blood cell lysis buffer (BD Pharm Lyse, BD Biosciences) diluted 1:10 in $\mathrm{H}_{2} \mathrm{O}$ and used at the concentration of 1$3 \times 10^{7} / \mathrm{ml}$.

\section{Cell count and calculation}

The digested lung cells were counted using a Neubauer hemacytometer (Fisher, Pittsburgh, PA). Dead cells were excluded by trypan blue (Sigma, St Louis, MO). The number of $\mathrm{CD}^{+} 1^{+}$cells was calculated by using flow cytometric analysis: $\left(\mathrm{CD} 31^{+}\right.$cell number $)=($total lung cell number $) \times\left(\%\right.$ of $\mathrm{CD}^{+} 1^{+}$cells among total cells $) / 100$. 


\section{DNA cell-cycle analysis}

For cell cycle analysis, the digested lung cells were stained at $1-2 \times 106$ cells $/ \mathrm{ml}$ with $10 \mathrm{uM}$ Hoechst 33342 (Invitrogen, Carlsbad, CA). After defining ModFit parameters (Modfit, Verity Software House, Topsham $\mathrm{ME})$, the viable lung cells were gated based on forward and side scatter parameters to exclude debris. In each experiment, the digested lung cells were stained at 1-2 $\times$ $10^{6}$ cells $/ \mathrm{ml}$ with $10 \mathrm{uM}$ Hoechst 33342 (Invitrogen, Carlsbad, CA) in media containing $2 \%$ fetal calf serum at pH7.2 for 60 minutes. The cells were immediately analyzed using a tri- excitation laser $(407 \mathrm{~nm}, 488 \mathrm{~nm}$ and $633 \mathrm{~nm} \mathrm{ex}$ ) and a FACSCanto II flow cytometer (BD Biosciences, Franklin Lakes, NJ). The samples were individually assessed to be within the guidelines of the DNA Consensus Conference criteria for quality (extrapolated to non-neoplastic tissue)[26]. After defining ModFit parameters, the viable lung cells were gated based on forward and side scatter parameters to exclude debris.The cells were analyzed by the ModFit autoanalysis and autolinearity algorithms (Verity Software House, Topsham ME). Because of nuclear density interference and other staining nonlinearities [27], the G2/G1 ratio was typically modified using the ModFit autolinearity algorithm. Autolinearity G2/G1 ratios ranged from 1.931.99. ModFit estimates of aggregates was $4.9 \pm 4.0 \%$ and debris was $13.4 \pm 5.8 \%$ of total events. The mean number of all cycle events was 74,996 \pm 12750 and the mean number of modeled events was 90,471 \pm 10359 .

\section{Flow cytometry}

For phenotypic analysis, the digested lung cells were incubated with a 5 -fold excess of directly conjugated fluorescein isothiocynate (FITC) or phycoerythrin (PE) anti-mouse antibodies with isotype controls: anti-CD31 (rat IgG2a, Clone 390, eBioscience)[28], anti-CD11b (rat IgG2b, Clone M1/70, BD Bioscience)[29] and anti-CD45 (rat IgG2b, Clone 30-F11, eBioscience)[30] prior to analysis using a tri-laser flow cytometer (BD FACSAria and FACSCanto II (BD Biosciences) with tri excitation laser (407 nm, $488 \mathrm{~nm}$ and $633 \mathrm{~nm}$ ex). The data were analyzed by FCS Express 4 software (De Novo Software, Los Angeles, CA). In all analyses, debris were eliminated by gating the alive cell population of side and forward light scatter and further by gating 7AAD (BD Biosciences)-negative population as previously described [31]. In most experiments, the analysis was based on 100,000 events.

\section{RNA and quantitative PCR}

In all RNA isolations, the total RNA quality was assessed by using an Agilent 2100 Bioanalyzer (Agilent Technologies, Palo Alto, CA). RNA integrity numbers (RIN) of the RNA samples were uniformly greater than
7.3 (mean 8.5; range 7.3 to 9.8)[32]. Real-time PCR was performed with SYBR green qPCR master mixes that include a chemically-modified hot start Taq DNA polymerase (SABiosciences, Frederick, MD). PCR was performed using an ABI Prism 7300 Real-Time PCR System (Applied Biosystems).

\section{PCR arrays}

The commercially available PCR arrays, obtained from S.A. Biosciences (Frederick, MD), included the Endothelial Cell Biology Array (PAMM-015), Inflammatory Cytokines and Receptors Array (PAMM-011), Dendritic \& Antigen Presenting Cell Array (PAMM-406) and the Angiogenesis Array (catalog PAMM-024). Real-time PCR was performed with SYBR green qPCR master mixes that include a chemically-modified hot start Taq DNA polymerase (SABioscience). PCR was performed on ABI 7300 Real-Time PCR System (Applied Biosystems, Carlsbad, CA). For all reactions, the thermal cycling conditions were $95^{\circ} \mathrm{C}$ for $10 \mathrm{~min}$ followed by 40 cycles of denaturation at $95^{\circ} \mathrm{C}$ for $15 \mathrm{sec}$ and simultaneous annealing and extension at $60^{\circ} \mathrm{C}$ for $1 \mathrm{~min}$. The two sets of triplicate control wells (RTC and PPC) were also examined for inter-well and intra-plate consistency; standard deviations of the triplicate wells were uniformly less than $1 C_{t}$. The variance of genes common to the 4 arrays were uniformly less than $0.5 \mathrm{C}_{\mathrm{t}}$. To reduce variance and improve inferences per array [33], a design strategy was used that combined pooled samples (3-4 mice per array).

\section{Statistics and bioinformatics}

Our quantitative PCR assumed that DNA template and/ or sampling errors were the same for all amplifications; our internal control replicates indicated that our sample size was sufficiently large that sampling errors were statistically negligible [34]. The exponential phase of the reaction was determined by a statistical threshold (10 standard deviations). Flow cytometry statistical analysis was based on measurements in at least three different mice. The unpaired Student's t-test for samples of unequal variances was used to calculate statistical significance. The data was expressed as mean \pm one standard deviation. The significance level for the sample distribution was defined as $\mathrm{P}<.05$. Clustering of the statistically significant genes ( $\mathrm{t}$-test; $\mathrm{p}<.05$ ) was performed using an agglomerative hierarchical clustering algorithm $[35,36]$.

\section{Results}

\section{Post-pneumonectomy lung growth}

To confirm a compensatory increase in lung volume after pulmonary resection, we studied the pulmonary mechanics of mice on Days 3, 6, 14, and 21 after left pneumonectomy. Using the FlexiVent rodent ventilator, 
the maximal vital capacity recruitment maneuver (referred to as the "TLC" volume by SciReq) demonstrated a statistically significant increase in lung volumes within 2 weeks of surgery (Figure 1A; p <.01). During the phase of greatest change in volume, immunohistochemistry of the lung using antibodies against the Ki-67 cell cycle protein demonstrated staining in the alveolar septa (Figure 1C). Nuclei positive for the Ki-67 protein were evident in both the alveolar septa and juxta-alveolar interstitium likely reflecting cell cycle activity in many lung cell types.

\section{Endothelial cells after pneumonectomy}

A quantitative assessment of the time course of cell proliferation was obtained using cell cycle flow cytometry of $\mathrm{CD} 31^{+}$endothelial cells (Figure 2). An early increase in S-phase cells was noted on Day 3 after pneumonectomy. By Day 6 after pneumonectomy, 10\% of the cells in the

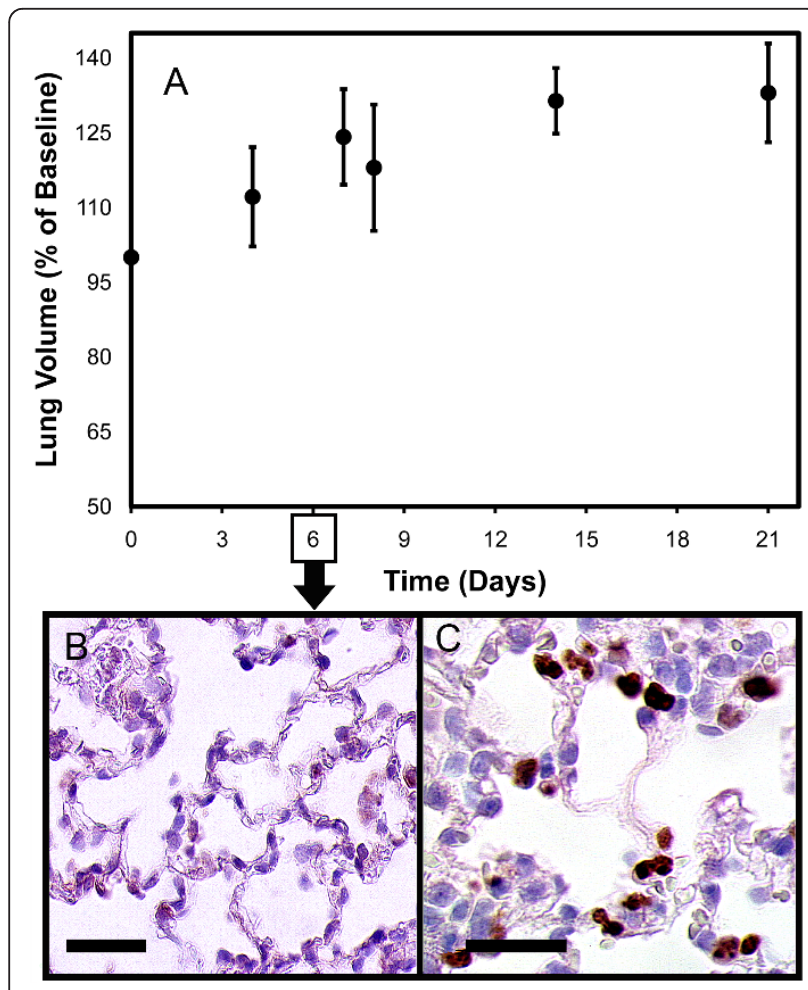

Figure 1 Functional and histologic evidence of compensatory lung growth after pneumonectomy (Day 0). A) Lung volumes obtained by a FlexiVent maximal vital capacity maneuver (named TLC by SCIREQ). The mouse was allowed to exhale to residual volume then ventilated with a $3 \mathrm{sec}$ ramp to a $3 \mathrm{sec}$ plateau at 30 $\mathrm{cmH}_{2} \mathrm{O}$ pressure. The measured volume was expressed as a percent of Day 0 post-pneumonectomy baseline. Each data point reflects the mean of $\mathrm{N}=3$ mice \pm 1 SD; 3 TLC maneuvers per mouse. B) Control and C) Ki-67 (Clone TEC-3, Dako, Hamburg, Germany) immunohistochemistry of the lung during the "growth" phase (Day 6) demonstrated scattered positive cells providing evidence of proliferation within the alveolar septa (arrow, bar $=25$ um). right lung were in either the S or G2 phases of the cell cycle. To investigate the endothelial response to pneumonectomy, the lung digests were analyzed by flow cytometry. Baseline analysis by flow cytometry demonstrated $8-15 \%$ of the cells were positive for the endothelial cell surface molecule CD31 (PECAM-1) and negative for leukocyte markers CD11b and CD45 (Figure 3A-D). As expected, the endothelial cells uniformly expressed the surface molecules VEGFR1 (Flt1) and CD31(Pecam1) (Figure 3E-F).

To confirm the cells isolated by flow cytometry were endothelial cells, the transcriptional profile was assessed by PCR arrays. Of note, the isolated RNA was consistently negative for leukocyte genes (Figure 4A), but positive for genes associated with endothelial cell functionassociated molecules, extracellular matrix molecules and angiogenesis and growth factor molecules (Figure 4B-D).

\section{Angiogenesis-related transcription}

To investigate the endothelial response to pneumonectomy, the transcriptional profile of the $\mathrm{CD} 31^{+}$cells on Days 3, 6, 14 and 21 after pneumonectomy was studied by PCR arrays. Volcano plots were used to identify gene transcription significantly increased or decreased relative to age-matched or sham thoracotomy control mice. At 3 days after pneumonectomy, no genes were significantly different from control $(\mathrm{p}<.05)$ with expression levels >4-fold controls; however, analyses 6 days after pneumonectomy identified 14 genes with differentially increased transcription (Figure 5B). Similarly, 17 genes demonstrated enhanced transcription 14 days after pneumonectomy (Figure 5C). In contrast, the RNA obtained from CD31 $1^{+}$cells 21 days after pneumonectomy demonstrated only 3 genes with increased expression (Figure 5D). Expression of 9 genes was increased at two or more time points (Col18a1, Col4a3, Csf3, Ereg, F2, Il6, Lect1, Sphk1, and Vegfa). None of the genes with decreased expression after pneumonectomy reached statistical significance with a $>4$-fold change. Of note, there was no significant difference in gene expression when sham thoracotomy and the no surgery controls were compared 14 days after pneumonectomy (Figure 5E). Similarly, the CD11b ${ }^{-}$CD $31^{-}$cells used for comparison in the gene expression analysis demonstrated temporal stability; there was little change in angiogenesis gene expression when the Day 0 and Day 14 post-pneumonectomy arrays were compared (Figure 5F).

\section{Temporal expression pattern}

The temporal patterning of the 84 genes in the angiogenesis PCR array was investigated using hierarchical clustering. Because of the wide variation in quantitative gene expression, we used pairwise Pearson correlation coefficients to assess similarity/dissimilarity. The genes 


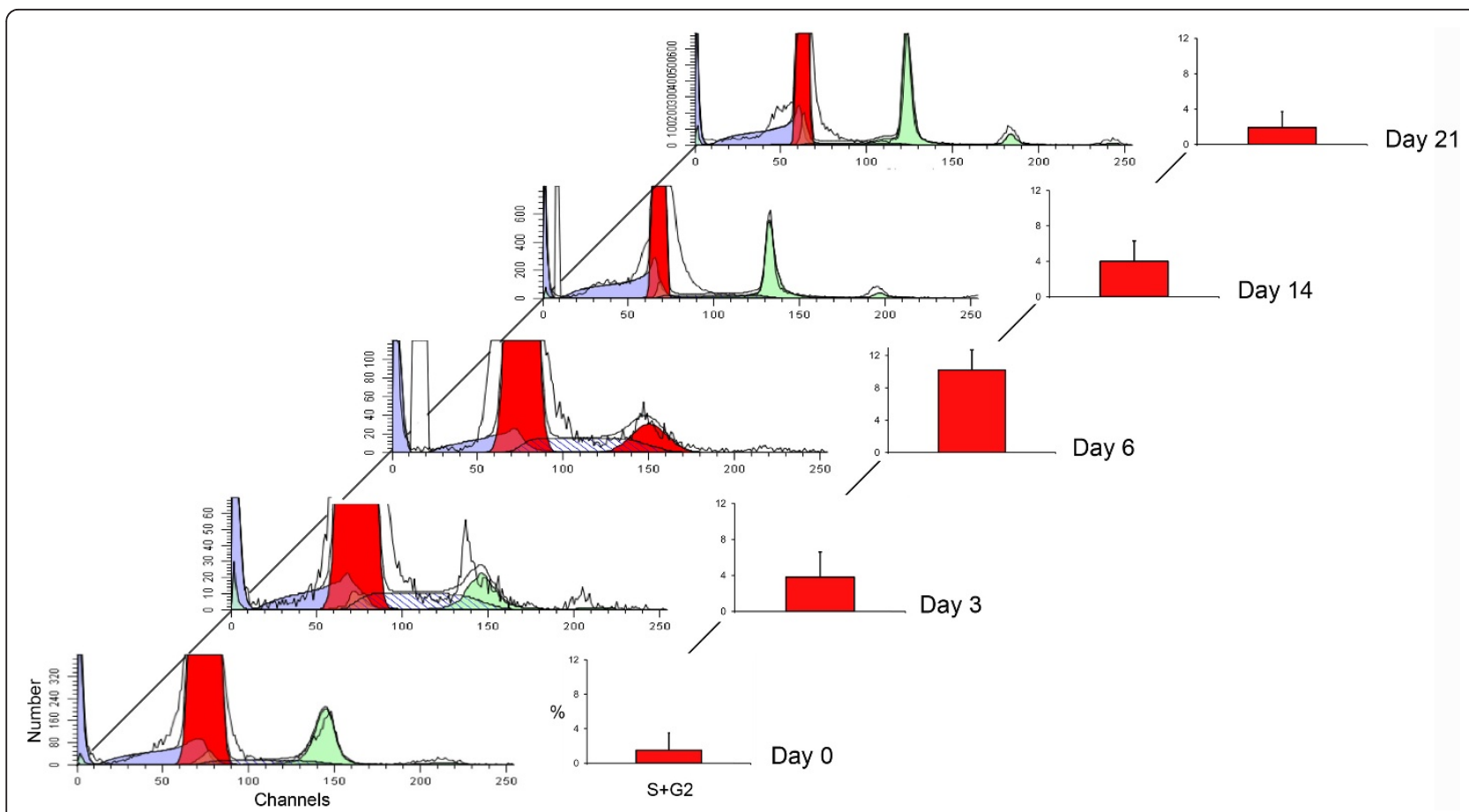

Figure 2 Cell cycle profiling of post-pneumonectomy lung $\mathrm{CD}_{3} 1^{+}$endothelial cells obtained by enzymatic digestion and analyzed using flow cytometry (ModFit, Verity Software House). Automated analysis of the ModFit model components, processed by a Marquardt nonlinear least-squares analysis, excluded aggregates (green) and identified S phase (blue hatched area) and G2 phase (second red peak) cells at five time points (Day $0,3,6,14$ and 21). The combined analysis of the percentage of cells in S+G2 phase of the cell cycle at various time points after pneumonectomy in the column chart (right; mean \pm SD; 4-6 mice per time point).

selected for clustering were 22 genes that demonstrated both a $>4$-fold change and a statistically significant $(\mathrm{p}$ $<.05)$ difference from control mice (Figure 6). Using this approach, gene expression clusters demonstrated unexpected similarities in genes such as Anpep and Thbs2, as well as functionally more predictable similarities in genes such as Ephb4 and Vegfa. Consistent with phases or "waves" of gene expression [37], distinct patterns were identified on Days 3, 6, 14 and 21. Most genes demonstrated a single wave of expression; only Csf 3 demonstrated a bimodal pattern with expression peaks on Days 6 and 21.

\section{Discussion}

In this report, we studied the expression of angiogenesis genes in isolated endothelial cells during murine postpneumonectomy lung growth. The quantitative profiling of 84 angiogenesis-associated genes suggested several conclusions. First, pneumonectomy resulted in a sustained transcriptional response in the lung endothelial cells. The persistent change in the expression of multiple angiogenesis-associated genes suggested a transcriptional "state" that persisted substantially longer than the 7-14 day growth period. Second, the statistically significant change in the expression of 22 angiogenesis- associated genes indicated that alveolar capillary angiogenesis did not depend upon a single dominant or controlling genetic element, but a complex sequence of gene expression. An understanding of these temporal dynamics will likely be necessary for effective therapeutic control. Finally, the use of an isolated cell population provided transcriptional evidence of intercellular signaling. The expression of genes known to participate in receptor-ligand pairs suggested testable predictions in complementary cell types.

A contribution of this study is the "tissue-scale" approach to post-pneumonectomy alveolar construction. Tissue-scale models typically consider individual cell types as "nodes" and the exchanges between cells as "edges" in computational networks. The structural composition of the lung-repeating functional units and relatively uniform cell types-makes this approach particularly appealing in the study of compensatory growth. In tissue-scale networks, any measurable or quantifiable property can be considered a variable of interest to be associated with a node. In adult morphogenesis, issues such as cell shape properties and the mechanical milieu are also among the variables associated with a node at this scale. Here, we studied a phenotypically uniform cell type (endothelial cells) and 

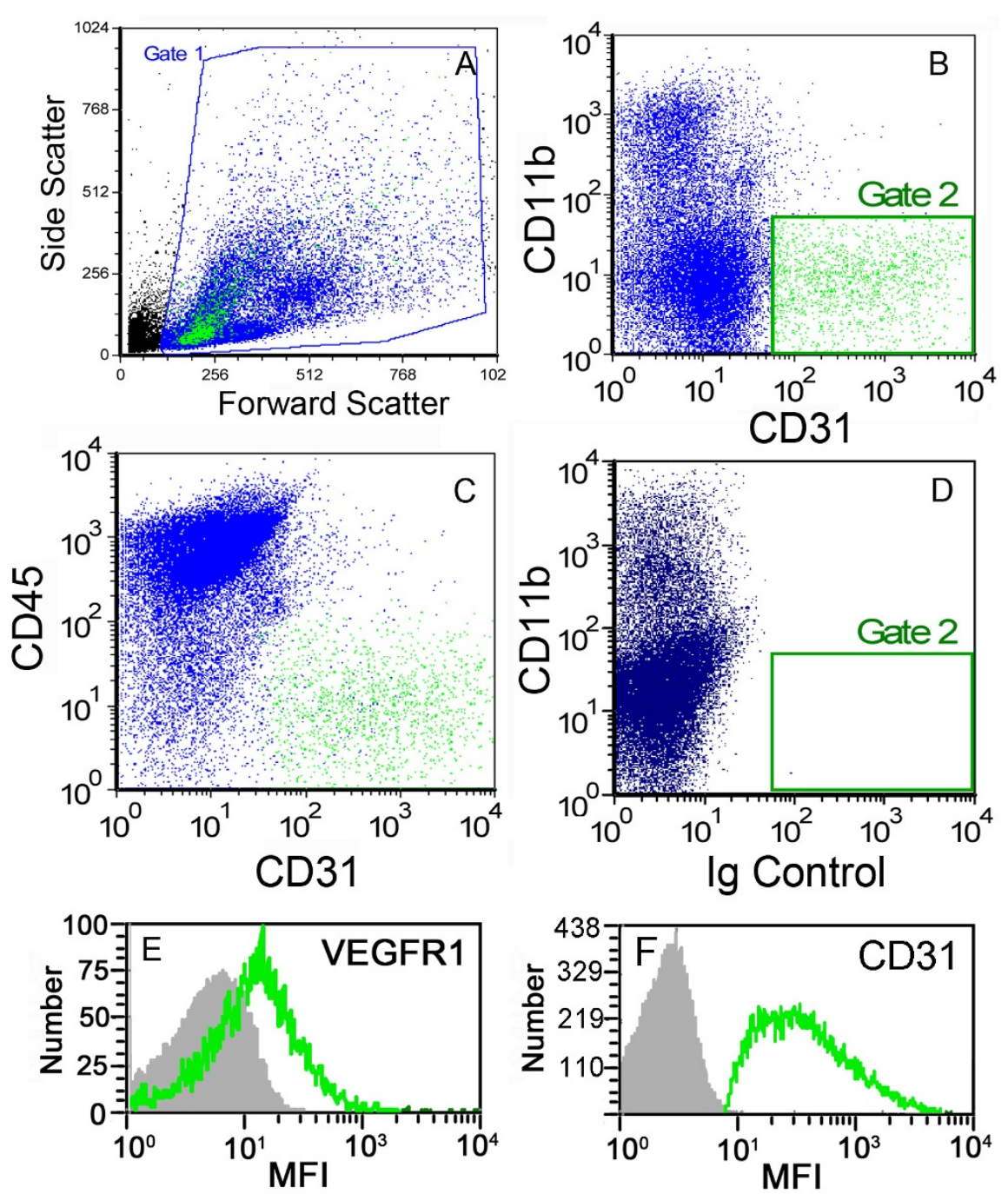

Figure 3 Phenotype of lung endothelial cells after enzymatic digestion. A) Flow cytometry light scatter characteristics of the digested lung cells. Gate 1 was used for subsequent dual parameter analyses. The green population in panels A-D reflect Gate 2 defined in panel B. B) Dual parameter histogram of lung cells stained with directly conjugated anti-CD31 (390, FITC) and anti-CD11b (M1/70, PE) monoclonal antibodies. C) Consistent with an endothelial phenotype, the CD31 $/$ CD $11 b^{-}$cells in Gate 2 were also negative for the leukocyte antigen CD45 (30-F11, PE). D) Isotype control of the anti-CD31 antibody. E-F) Surface expression of the Flt1 (VEGFR1) and Pecam1 (CD31) gene products of the endothelial cell population presented as a single parameter histogram. Gray reflects the surface staining of the isotype control of each antibody; MFI = mean fluorescence intensity. The $\mathrm{CD}_{3} 1^{+}$cells (Gate 2) were defined as endothelial cells for subsequent experiments.

analyzed the transcriptional profile associated with the morphogenetic process of angiogenesis. We anticipate that the value of this data will grow as 1) other nodes in the tissue-scale network are defined, and 2) more endothelial cell variables are characterized.

Our data indicate that compensatory growth was not associated with a single transcriptional wave, but a temporal pattern of gene expression. The concept of a temporal dynamics of gene expression has been explored in many developmental studies [38,39]. In most cases, the patterns of gene expression are presumed to reflect a largely context-insensitive linear cascade of genes with sequentially ordered expression [40]. An alternative interpretation is that the temporal dynamics reflect network interactions with intercellular signaling and feedback control. For example, the enhanced expression of Ereg (epigregulin) in endothelial cells suggests a complementary target receptor on epithelial cells. Ereg is a member of the epidermal growth factor family and can function as a ligand of EGFR (epidermal growth factor receptor), as well as a ligand of most members of the ERBB (v-erb-b2 oncogene homolog) family of tyrosinekinase receptors. Since EGFR is expressed on all epithelial and stromal cells [41], the transcription of Ereg by 

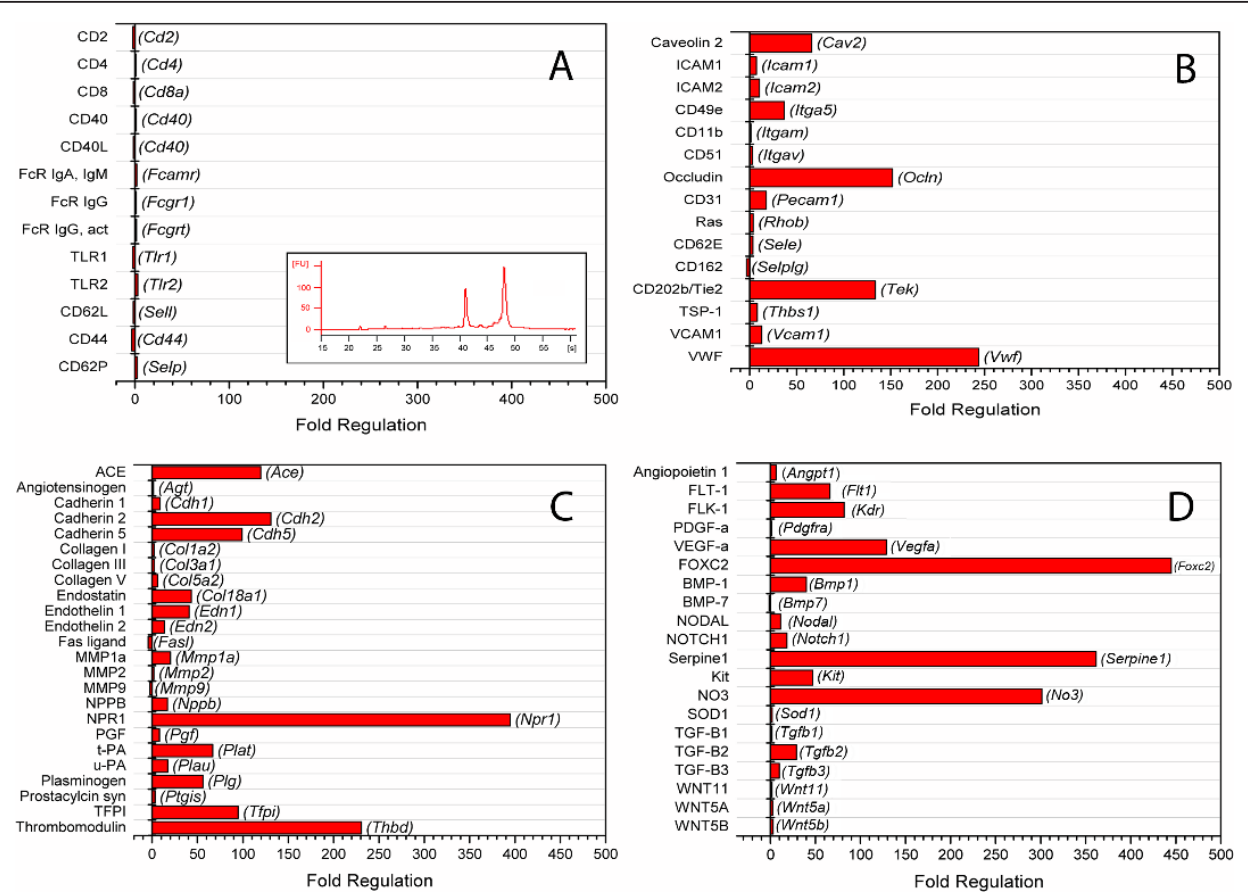

Figure 4 Representative gene transcription profile of $\mathrm{CD} 31^{+}$cells. Baseline (control) lungs were enzymatically digested and the $\mathrm{CD} 31^{+}$cells isolated by flow cytometry cell sorting. The RNA extracted from $\mathrm{CD}_{3} 1^{+}$cells consistently demonstrated RIN greater than 8 (inset: representative RNA electropherogram). The CD31 ${ }^{+}$cells were compared to CD31/CD1 1 b cells on multiple PCR arrays (PAMM-015, PAMM-011 and PAMM-406, SABiosciences). The $\mathrm{CD} 31^{+}$cell gene transcription profile, expressed as the fold regulation ( $\log _{2}$ ), was grouped by phenotypic and functional associations: A) leukocyte membrane molecules, B) endothelial cell function-associated molecules, C) extracellular matrix molecules and D) angiogenesis and growth factor molecules. Data representative of $\mathrm{N}=16$ mice.

endothelial cells suggests a growth promoting interaction between these cell types. Perhaps relevant to the post-pneumonectomy milieu, Ereg has been implicated in smooth muscle proliferation and differentiation [41], mechanical strain [42] and wound healing [43]. We predict that future studies of isolated epithelial cells will demonstrate the coexpression of complementary receptor-ligand gene pairs.

The number of identifiable waves of gene expression was a consequence of our experimental design: we studied lungs 3, 6, 14 and 21 days after pneumonectomy. The time points were chosen to reflect the tempo of angiogenesis in the developing rat lung. Burri et al. have described several phases of postnatal lung growth within 21 days: expansion of the lung, rapid alveolarization, and septal restructuring $[44,45]$. To provide an overview of the entire growth period, we have defined the transcriptional pattern over this 21 day period. An alternative time course is suggested by morphometric studies [13]. In these investigations, the authors demonstrated a significant increase in alveolar number by 6 days after pneumonectomy. A goal of future studies will be to concentrate on the earlier phase of endothelial cell transcription (0-6 days) and enhance the resolution of the pattern described here.
Our findings have several practical limitations. Foremost, we used quantitative PCR arrays to identify statistical significance (t-test) within and between time points, but de-emphasized the fold regulation of gene expression. Contemporary qRT-PCR arrays provide a quantitative assessment of gene expression relative to housekeeping genes $\left(\Delta \mathrm{C}_{\mathrm{t}}\right)$ and control or calibrator samples $\left(\Delta \Delta \mathrm{C}_{\mathrm{t}}\right)$ [46]. Although this method obviates the need for producing a standard curve for each gene, "fold regulation" can be misleading. For example, the kinase insert domain receptor $K d r$ encodes the VEGFR2 receptor and functions as an important mediator of VEGFinduced endothelial proliferation [47]. Post-pneumonectomy $K d r$ expression was only 2-3-fold higher than nonpneumonectomy controls, but 80 -fold higher in endothelial cells than in the $\mathrm{CD} 31^{-} \mathrm{CD} 11 \mathrm{~b}^{-}$(primarily epithelial cells) controls. Thus, the biological implications of a 2-fold change in a highly transcribed gene are likely to be substantially different from a 2 -fold change in a gene with little or no baseline transcription. Because of the limitations of "fold regulation," we emphasized the patterns of expression rather than absolute levels of expression. We used temporal co-expression as a tool for identifying functional relationships. Although our temporal clustering analysis was based on 

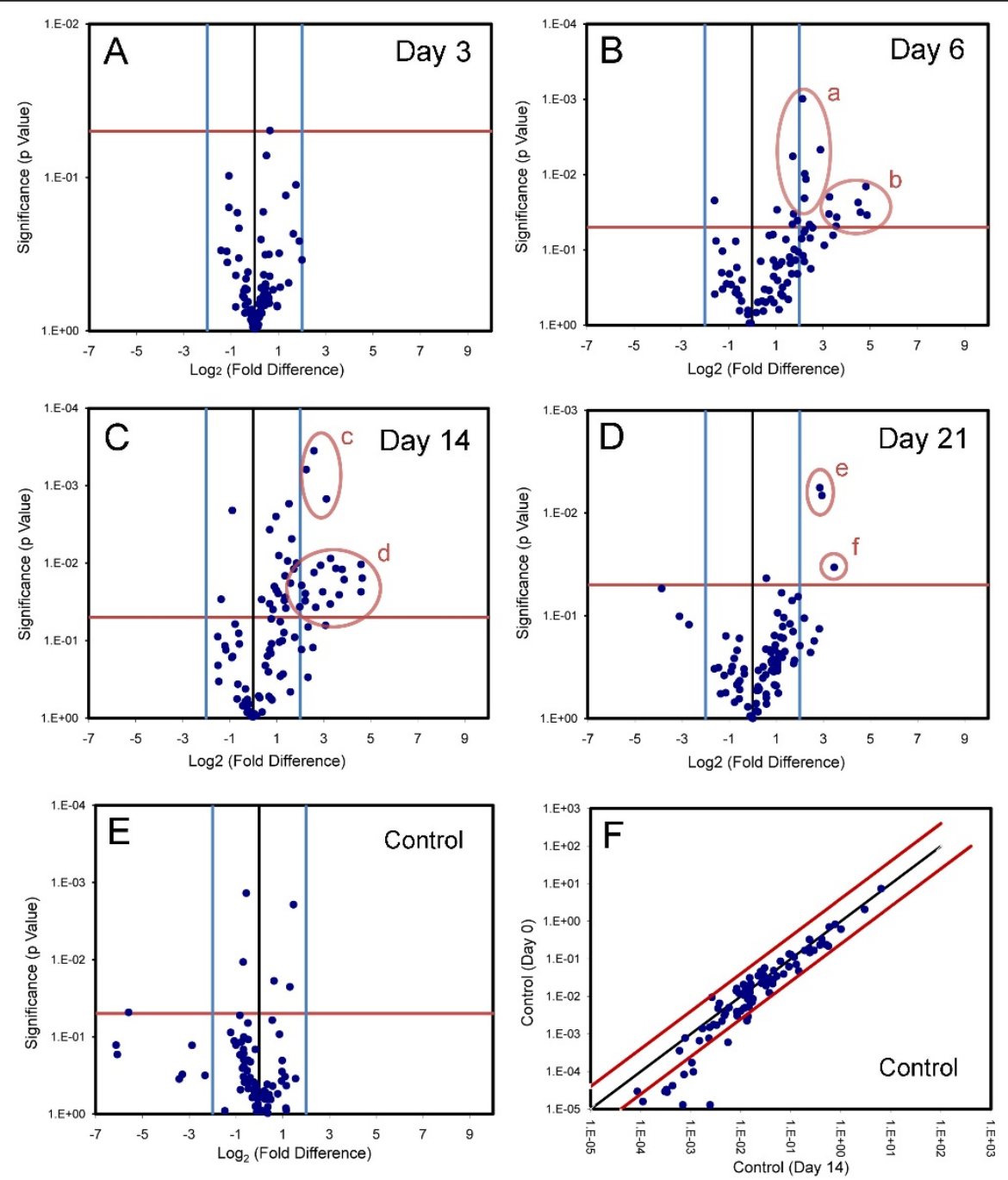

Figure 5 Expression of angiogenesis-related genes in $\mathrm{CD} 31^{+}$cells after pneumonectomy. A-D) Gene expression in mice 3, 6, 14 and 21 days after pneumonectomy was compared to age-matched controls without surgery. The $\log _{2}$ fold-change in gene expression was plotted against the p-value (t-test) to produce a "volcano plot." The vertical threshold reflected the relative statistical significance (red horizontal line, $-\log _{10}, p<0.05$ ); the horizontal threshold reflected the relative fold-change in gene expression (blue vertical line, 4-fold). The significantly upregulated expression of specific genes (red elipses): a) Tnfaip2, Plg, Anpep, Pgf, Vegfb and Thbs2; b) Csf3, Col4a3, Sphk1, Ereg, Vegfa, Lect1, Col18a1 and I16; C) Ereg, Ephb4 and Vegfa; d) Tbx1, Cxc15, Col4a3, Col18a1, F2, Vegfc, Sphk1, Col11, S1pr1, F2, Il6, Lect1, Flt1 and Csf3. e) Sphk1 and Vegfa; f) Csf3. Each data point reflects triplicate or quadruplicate arrays of 9 to 21 mice (Day 0, N=15 mice; Day 3, N=9 mice; Day $6=9$ mice; Day 14, $\mathrm{N}=9$ mice; Day 21, $\mathrm{N}=21$ mice). E) Indicating a limited impact of the thoracotomy alone, the volcano plot comparison of sham thoracotomy and no surgery control demonstrated no significant change in gene expression on Day 14 after pneumonectomy. F) Scattergram indicating the

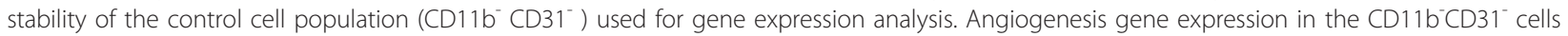
was compared on Day 0 and Day 14 after pneumonectomy ( $N=3$ mice, each time point). Gene expression demonstrated only one gene (Bail) with significantly decreased expression on Day 14 after pneumonectomy.

simple correlation coefficients, patterns of expression over time can lead to more sophisticated approaches, such as time-lagged correlations, to infer functional relationships [48].

Flow cytometry, an instrument that uniquely analyzes samples on a per cell basis, provided several advantages in our study. First, flow cytometry permitted the isolation of a large population of phenotypically uniform endothelial cells; that is, cells central to both the functional regulation and structural development of new blood vessels. Second, simultaneous analysis and sorting by flow cytometry provided a link between molecular expression and gene transcription [36]. In this report, we limited our analysis to Pecam 1 and Flt1 gene products-namely, the CD31 and VEGFR1 membrane molecules-but a similar approach is applicable to many of 


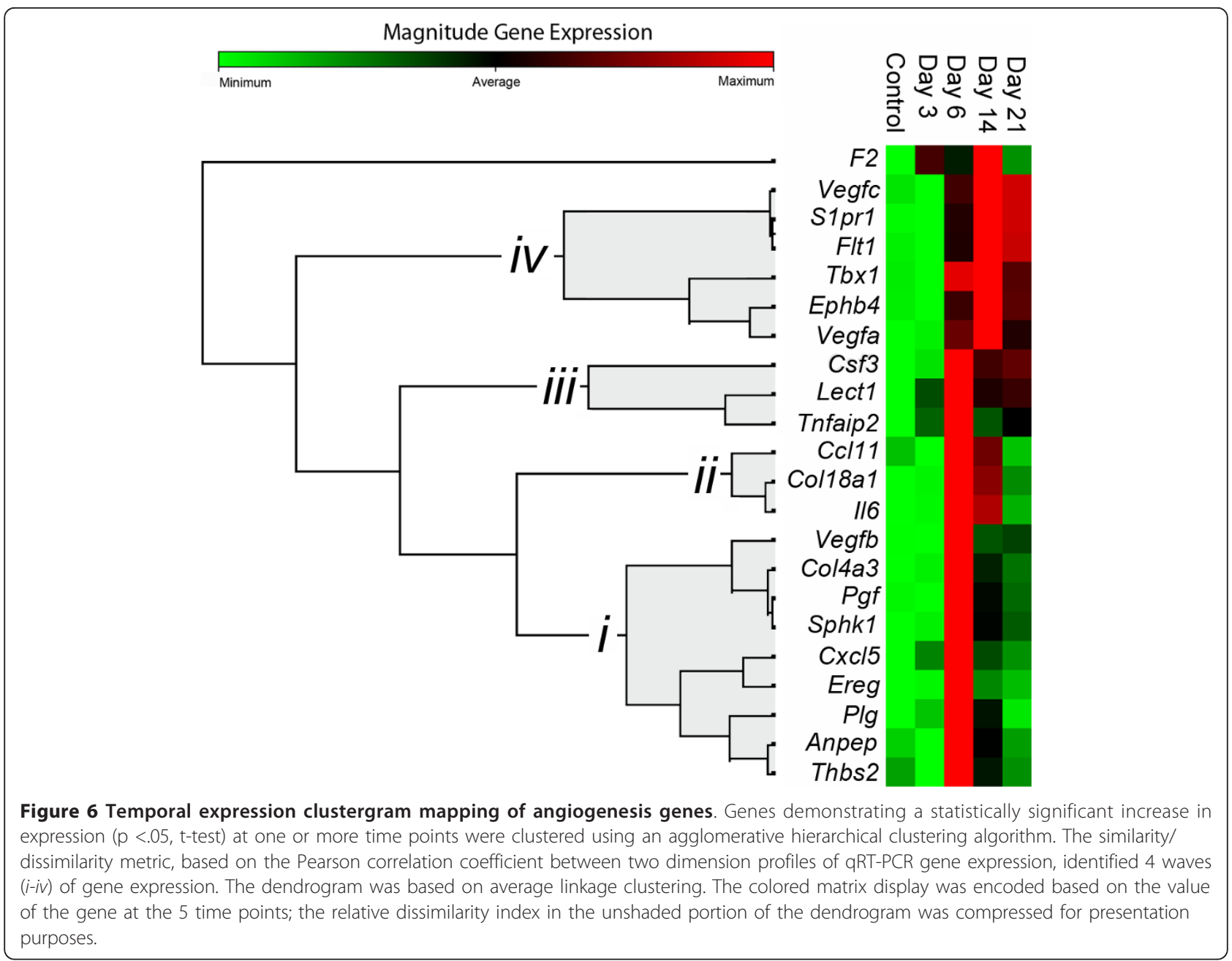

the genes identified in the PCR arrays. Third, since the cell membrane defines a basic regulatory unit of the genome, sorting endothelial cells approximated a uniform transcriptional network [49]. Sorting a population of endothelial cells, rather than using bulk tissue, is analogous to studying the relatively uniform cell populations that have facilitated insights into transcriptional programs in bacteria [50].

The dominant wave of gene transcription occurred on Day 6 after pneumonectomy. Angiogenesis genes such as Ereg, Lect1, Plg, and Csf3 demonstrated a significant increase in expression on Day 6 (6- to 30-fold). Interestingly, Vegfa expression continued to rise slightly until Day 14-resulting in a slightly misleading temporal clustergram. Vegfa has been previously associated with pulmonary capillary development; the selective inactivation of the Vegfa gene results in almost complete absence of pulmonary capillaries [51]. The increased expression of $V e g f a$ in endothelial cells, however, suggested the possibility of an autocrine effect of Vegfa [52] or a trophic influence on other components of the regenerating alveolus. VEGF effects on alveolar type II cells include the activation of cell proliferation, the stimulation of surfactant production [53] and the inhibition of apoptosis [54]. VEGFR1, a membrane receptor stimulated by both VEGFA and VEGFB, has been implicated in the positive regulation of monocyte and macrophage migration [55].

Finally, expression of genes associated with the regulation of angiogenesis also occurred on Days 6 and 14 after pneumonectomy. Angiogenesis genes such as Col18a, Col4a3 and Plg are known to participate in angiogenesis, but are also the precursors to angiogenesis inhibitors [56]. For example, endostatin is the proteolytic cleavage protein of collagen XVIII and angiostatin is derived from plasminogen [57]. Similarly, the C-terminal cleavage products of collagen IV $\alpha 1, \alpha 2$ and $\alpha 3$ possess anti-angiogenic activities; the most notable example is the fragment of the $\alpha 3$ chain of type IV collagen referred to as tumstatin [58]. The varied expression of these genes indicates that post-pneumonectomy angiogenesis involves an interactive and interdependent 
network of both positive and negative signals; a process likely involving feedback control.

In summary, we have used a "tissue-scale" approach to investigate endothelial cell participation in post-pneumonectomy lung growth. By using flow cytometry to isolate $\mathrm{CD} 31^{+}$endothelial cells and PCR arrays to quantify gene expression, we have 1) contributed gene expression data to the endothelial cell "node" in tissuescale growth networks, and 2) provided insights into the process of alveolar angiogenesis. Analysis of gene expression in the endothelial cell "node" did not demonstrate a single regenerative signal but a temporal pattern of gene expression. The known physiologic functions of the expressed genes suggest that gene expression does not reflect a pre-programmed response, but a highly interactive and interdependent signaling network. To test our predictions, future work will define other cell types ("nodes") and the exchanges between cells ("edges") for subsequent analysis in computational networks of post-pneumonectomy lung growth.

\section{Abbreviations}

Ct: cycle threshold; EGFR: epidermal growth factor receptor; FITC: fluorescein isothiocynate; mAb: monoclonal antibodies; PBS: phosphate buffered saline; PCR: polymerase chain reaction; PEEP: positive end expiratory pressure; PE: phycoerythrin; PPC: positive PCR controls; qRT-PCR: quantitative real-time PCR; RIN: RNA integrity number; RTC: reverse transcription controls; SD: standard deviation

\section{Acknowledgements}

Supported by NIH Grant HL75426 and HL94567 and HL007734 as well as the Uehara Memorial Foundation and the JSPS Postdoctoral Fellowships for Research Abroad.

\section{Author details}

'Laboratory of Adaptive and Regenerative Biology, Brigham \& Women's Hospital, Harvard, Medical School, Boston MA, USA. Institute of Functional and Clinical Anatomy, University Medical Center of the Johannes GutenbergUniversity Mainz, Germany. ${ }^{3}$ Molecular and Integrative Physiological Sciences, Harvard School of Public Health, Boston, MA, USA.

\section{Authors' contributions}

Author contribution: All authors have read and approved the manuscript. ML and KC supervised the flow cytometry and PCR experiments; BCG and JH performed the pneumonectomies; GSL and DCS performed the experiments and analyzed the data. MAK, AT and SJM contributed to experimental design, data analysis and manuscript development.

\section{Competing interests}

The authors declare that they have no competing interests.

Received: 2 February 2011 Accepted: 27 July 2011

Published: 27 July 2011

\section{References}

1. Degraff AC, Grover RF, Johnson RL, Hammond JW, Miller JM: Diffusing capacity of lung in caucasians native to 3,100 m. J Appl Physiol 1970, 29(1):71-76.

2. Hopkins N, McLoughlin P: The structural basis of pulmonary hypertension in chronic lung disease: remodelling, rarefaction or angiogenesis? J Anat 2002, 201(4):335-348.

3. Schraufnagel DE: Monocrotaline-induced angiogenesis. Differences in the bronchial and pulmonary vasculature. Am J Pathol 1990, 137(5):1083-1090.
4. Ravnic DJ, Konerding MA, Pratt JP, Wolloscheck T, Huss HT, Mentzer SJ: The murine bronchopulmonary microcirculation in hapten-induced inflammation. J Thorac Cardiovasc Surg 2007, 133:97-103.

5. Grover RF, Wagner WW, McMurtry IF, Reeves JT: Pulmonary circulation. In Handbook of Physiology The Cardiovascular System, Peripheral Circulation and Organ Blood Flow. Volume 3. Bethesda: Am. Physiol. Soc; 1983:103-136.

6. Schraufnagel DE, Malik R, Goel V, Ohara N, Chang SW: Lung capillary changes in hepatic cirrhosis in rats. Am J Physiol-Lung Cell Mol Physiol 1997, 272(1):L139-L147.

7. Hopkins N, Cadogan E, Giles S, McLoughlin P: Chronic airway infection leads to angiogenesis in the pulmonary circulation. J Appl Physiol 2001, 91(2):919-928.

8. Nannmark U, Johansson BR, Bryant JL, Unger ML, Hokland ME, Goldfarb RH, Basse PH: Microvessel origin and distribution in pulmonary metastases of B16 melanoma: implication for adoptive immunotherapy. Cancer Res 1995, 55(20):4627-4632.

9. Hsia CCW, Herazo LF, Fryderdoffey F, Weibel ER: Compensatory lung growth occurs in adult dogs after right pneumonectomy. J Clin Investig 1994, 94(1):405-412.

10. Addis T: Compensatory hypertrophy of the lung after unilateral pneumectomy. J Exp Med 1928, 47(1):51-56.

11. Brody JS, Burki R, Kaplan N: Deoxyribonucleic-acid synthesis in lung-cells during compensatory lung growth after pneumonectomy. Am Rev Respir Dis 1978, 117(2):307-316.

12. Heuer GJ, Dunn GR: Experimental pneumectomy. Bull Johns Hopkins Hosp 1920, 31:31-42.

13. Fehrenbach $H$, Voswinickel R, Michl V, Mehling T, Fehrenbach A, Seeger W, Nyengaard JR: Neoalveolarisation contributes to compensatory lung growth following pneumonectomy in mice. Eur Respir J 2008, 31(3):515-522.

14. Muhlfeld C, Weibel ER, Hahn U, Kummer W, Nyengaard JR, Ochs M: Is Length an Appropriate Estimator to Characterize Pulmonary Alveolar Capillaries? A Critical Evaluation in the Human Lung. Anat Rec 2010, 293(7):1270-1275.

15. Landesberg $L$, Ramalingam R, Lee K, Rosengart TK, Crystal RG: Upregulation of transcription factors in lung in the early phase of postpneumonectomy lung growth. Am J Physiol Lung Cell Mol Physiol 2001, 281(5):L1138-1149.

16. Kaza AK, Kron IL, Leuwerke SM, Tribble CG, Laubach VE: Keratinocyte growth factor enhances post-pneumonectomy lung growth by alveolar proliferation. Circulation 2002, 106:1120-1124.

17. Sakamaki Y, Matsumoto K, Mizuno S, Miyoshi S, Matsuda H, Nakamura T: Hepatocyte growth factor stimulates proliferation of respiratory epithelial cells during postpneumonectomy compensatory lung growth in mice. Am J Respir Cell Mol Biol 2002, 26(5):525-533.

18. Zhang Q, Bellotto DJ, Ravikumar P, Moe OW, Hogg RT, Hogg DC, Estrera AS, Johnson RL Jr, Hsia CC: Postpneumonectomy lung expansion elicits hypoxia-inducible factor-1alpha signaling. Am J Physiol Lung Cell Mol Physiol 2007, 293(2):L497-504.

19. Leuwerke SM, Kaza AK, Tribble CG, Kron IL, Laubach VE: Inhibition of compensatory lung growth in endothelial nitric oxide synthase-deficient mice. Am J Physiol Lung Cell Mol Physiol 2002, 282(6):L1272-1278.

20. Yuan SZ, Hannam V, Belcastro R, Cartel N, Cabacungan J, Wang JX, Diambomba Y, Johnstone L, Post M, Tanswell AK: A role for plateletderived growth factor-BB in rat postpneumonectomy compensatory lung growth. Pediatr Res 2002, 52(1):25-33.

21. Jancelewicz T, Grethel EJ, Chapin CJ, Clifton MS, Nobuhara KK: Vascular Endothelial Growth Factor Isoform and Receptor Expression During Compensatory Lung Growth. J Surg Res 2008, 160(1):107-113.

22. Paxson JA, Parkin CD, lyer LK, Mazan MR, Ingenito EP, Hoffman AM: Global gene expression patterns in the post-pneumonectomy lung of adult mice. Respir Res 2009, 10(92):1-15.

23. Wolff JC, Wilhelm J, Fink L, Seeger W, Voswinckel R: Comparative gene expression profiling of post-natal and post-pneumonectomy lung growth. Eur Respir J 2010, 35(3):655-666.

24. Gibney B, Lee GS, Houdek J, Lin M, Chamoto K, Konerding MA, Tsuda A, Mentzer SJ: Dynamic determination of oxygenation and lung compliance in murine pneumonectomy. Exp Lung Res 2011, 37:301-309.

25. Abdi K, Rogers RA, Li X, Lopez P, Rawn J, Mentzer SJ: In situ fluorescence labeling of sheep lung microvascular endothelium. In Vitro Cell Dev Biol Anim 1995, 31(4):310-315. 
26. Shankey TV, Rabinovitch PS, Bagwell B, Bauer KD, Duque RE, Hedley DW Mayall BH, Wheeless L: Guidelines for implementation of clinical DNA cytometry. Cytometry 1993, 14(5):472-477.

27. Wersto RP, Chrest FJ, Leary JF, Morris C, Stetler-Stevenson M, Gabrielson E: Doublet discrimination in DNA cell-cycle analysis. Cytometry 2001, 46(5):296-306.

28. Baldwin HS, Shen HM, Yan HC, DeLisser HM, Chung A, Mickanin C, Trask T, Kirschbaum NE, Newman PJ, Albelda SM, et al: Platelet endothelial cell adhesion molecule-1 (PECAM-1/CD31): Alternatively spliced, functionally distinct isoforms expressed during mammalian cardiovascular development. Development 1994, 120:2539-2553.

29. Springer T, Galfre G, Secher DS, Milstein C: MAC-1 - a macrophage differentiation antigen identified by monoclonal antibody. Eur J Immunol 1979, 9(4):301-306.

30. Ledbetter JA, Herzenberg LA: Xenogeneic monoclonal antibodies to mouse lymphoid differentiation antigens. Immunol Rev 1979, 47:63-90.

31. Su M, He C, West CA, Mentzer SJ: Cytolytic peptides induce biphasic permeability changes in mammalian cell membranes. JlmmunolMethods 2001, 252(1-2):63-71.

32. Schroeder A, Mueller O, Stocker S, Salowsky R, Leiber M, Gassmann M, Lightfoot S, Menzel W, Granzow M, Ragg T: The RIN: an RNA integrity number for assigning integrity values to RNA measurements. BMC Mol Biol 2006, 7:1-14

33. Kendziorski $C$, Irizarry RA, Chen $K S$, Haag JD, Gould MN: On the utility of pooling biological samples in microarray experiments. Proc Natl Acad Sci USA 2005, 102(12):4252-4257.

34. Stolovitzky G, Cecchi G: Efficiency of DNA replication in the polymerase chain reaction. Proc Natl Acad Sci USA 1996, 93(23):12947-12952.

35. Pratt JP, Zeng QT, Ravnic D, Rawn J, Huss H, Mentzer SJ: Heirarchical clustering of antibody reactivity patterns in non-human species. Cytometry 2009, 75(9):734-742.

36. Zeng QT, Pratt JP, Pak J, Ravnic D, Huss H, Mentzer SJ: Feature-guided clustering of multi-dimensional flow cytometry datasets. J Biomed Inform 2007, 40(3):325-331.

37. Wen XL, Fuhrman S, Michaels GS, Carr DB, Smith S, Barker JL, Somogyi R: Large-scale temporal gene expression mapping of central nervous system development. Proc Natl Acad Sci USA 1998, 95(1):334-339.

38. Kho AT, Bhattacharya S, Mecham BH, Hong J, Kohane IS, Mariani TJ: Expression Profiles of the Mouse Lung Identify a Molecular Signature of Time-to-Birth. Am J Respir Cell Mol Biol 2009, 40(1):47-57.

39. Yosef N, Regev A: Impulse Control: Temporal Dynamics in Gene Transcription. Cell 2011, 144(6):886-896.

40. Wells A: EGF receptor. Int J Biochem Cell Biol 1999, 31(6):637-643.

41. Taylor DS, Cheng XB, Pawlowski JE, Wallace AR, Ferrer P, Molloy CJ: Epiregulin is a potent vascular smooth muscle cell-derived mitogen induced by angiotensin II, endothelin-1, and thrombin. Proc Natl Acad Sci USA 1999, 96(4):1633-1638.

42. Yang R, Amir J, Liu HB, Chaqour B: Mechanical strain activates a program of genes functionally involved in paracrine signaling of angiogenesis. Physiol Genomics 2008, 36(1):1-14.

43. Roy S, Khanna S, Rink C, Biswas S, Sen CK: Characterization of the acute temporal changes in excisional murine cutaneous wound inflammation by screening of the wound-edge transcriptome. Physiol Genomics 2008, 34(2):162-184.

44. Burri PH, Dbaly J, Weibel ER: Postnatal-growth of rat lung.1. Morphometry. Anat Rec 1974, 178(4):711-730.

45. Caduff $\mathrm{JH}$, Fischer LC, Burri PH: Scanning electron microscope study of the developing microvasculature in the postnatal rat lung. Anat Rec 1986, 216(2):154-164.

46. Livak KJ, Schmittgen TD: Analysis of relative gene expression data using real-time quantitative $P C R$ and the 2(-Delta Delta $C(T)$ ) Method. Methods 2001, 25(4):402-408.

47. Tsopanoglou NE, Maragoudakis ME: On the mechanism of thrombininduced angiogenesis. Potentiation of vascular endothelial growth factor activity on endothelial cells by up-regulation of its receptors. J Biol Chem 1999, 274(34):23969-23976.

48. Schmitt WA, Raab RM, Stephanopoulos G: Elucidation of gene interaction networks through time-lagged correlation analysis of transcriptional data. Genome Res 2004, 14(8):1654-1663.

49. Segal E, Shapira M, Regev A, Pe'er D, Botstein D, Koller D, Friedman N: Module networks: identifying regulatory modules and their condition- specific regulators from gene expression data. Nat Genet 2003, 34(2):166-176.

50. Csete ME, Doyle JC: Reverse engineering of biological complexity. Science 2002, 295(5560):1664-1669.

51. Yamamoto H, Yun EJ, Gerber HP, Ferrara N, Whitsett JA, Vu TH: Epithelialvascular cross talk mediated by VEGF-A and HGF signaling directs primary septae formation during distal lung morphogenesis. Dev Biol 2007, 308(1):44-53.

52. Tokuyama W, Mikami T, Masuzawa M, Okayasu I: Autocrine and paracrine roles of VEGF/VEGFR-2 and VEGF-C/VEGFR-3 signaling in angiosarcomas of the scalp and face. Hum Pathol 2010, 41(3):407-414.

53. Compernolle V, Brusselmans K, Acker T, Hoet P, Tjwa M, Beck H, Plaisance $S$, Dor Y, Keshet E, Lupu F, et al: Loss of HIF-2 and inhibition of VEGF impair fetal lung maturation, whereas treatment with VEGF prevents fatal respiratory distress in premature mice. Nature Medicine 2002, 8(7):702-710.

54. Gerber HP, Dixit V, Ferrara N: Vascular endothelial growth factor induces expression of the antiapoptotic proteins $\mathrm{BCl}-2$ and $\mathrm{A} 1$ in vascular endothelial cells. J Biol Chem 1998, 273(21):13313-13316.

55. Olsson AK, Dimberg A, Kreuger J, Claesson-Welsh L: VEGF receptor signalling - in control of vascular function. Nat Rev Mol Cell Biol 2006, 7(5):359-371

56. Tabruyn SP, Griffioen AW: Molecular pathways of angiogenesis inhibition. Biochem Biophys Res Commun 2007, 355(1):1-5.

57. Nyberg P, Xie L, Kalluri R: Endogenous inhibitors of angiogenesis. Cancer Res 2005, 65(10):3967-3979.

58. Maeshima Y, Sudhakar A, Lively JC, Ueki K, Kharbanda S, Kahn CR, Sonenberg N, Hynes RO, Kalluri R: Tumstatin, an endothelial cell-specific inhibitor of protein synthesis. Science 2002, 295(5552):140-143.

doi:10.1186/1465-9921-12-98

Cite this article as: Lin et al.: Angiogenesis gene expression in murine endothelial cells during post-pneumonectomy lung growth. Respiratory Research 2011 12:98.

\section{Submit your next manuscript to BioMed Central and take full advantage of:}

- Convenient online submission

- Thorough peer review

- No space constraints or color figure charges

- Immediate publication on acceptance

- Inclusion in PubMed, CAS, Scopus and Google Scholar

- Research which is freely available for redistribution

Submit your manuscript at www.biomedcentral.com/submit
C Biomed Central 